Available online on 20.04.2018 at http://jddtonline.info
Journal of Drug Delivery and Therapeutics
Open Access to Pharmaceutical and Medical Research
$\begin{gathered}\text { (c) 2011-18, publisher and licensee JDDT, This is an Open Access article which permits unrestricted non- } \\ \text { commercial use, provided the original work is properly cited }\end{gathered}$

Open Access

Research Article

\title{
FLOW AND COMPACTION PROPERTIES OF THE MODIFIED BIOMATERIAL POWDER DERIVED FROM THE TYMPANOTONUS FUSCATA SHELL
}

\author{
Kenneth C. Ugoeze ${ }^{1 *}$, Amarauche Chukwu² \\ ${ }^{1}$ Department of Pharmaceutics \& Pharmaceutical Technology, Faculty of Pharmaceutical Sciences, University of Port Harcourt, \\ Nigeria \\ ${ }^{2}$ Department of Pharmaceutical Technology and Industrial Pharmacy, Faculty of Pharmaceutical Sciences, University of Nigeria, \\ Nsukka, Nigeria
}

\begin{abstract}
A modified biomaterial powder derived from Tympanotonus fuscata shell was evaluated for its flow and compaction properties towards possible application in the directly compressible technology of tablet production. The pulverized periwinkle shell was digested in hydrochloric acid, neutralized, precipitated with ortho-phosphoric acid, and dried to a constant weight at $60{ }^{\circ} \mathrm{C}$. The product was coded MBPSP. The densities and flow parameters of MBPSP was assessed using a Stampf volumeter and the Kawakita model, while its compaction behaviour was assessed using the Heckel model. Emcompress ${ }^{\circledR}$ and Avicel PH $101^{\circledR}$ were employed as standards. The MBPSP powder showed evidence of densification and consolidation on tapping (bulk and tapped densities $0.42 \pm$ 0.01 and $0.68 \pm 0.01)$, while the angle of repose $(35.18 \pm 0.49)$, flow rate $(8.94 \pm 0.13 \mathrm{~g} / \mathrm{s})$ and Carr's index $(27.25 \pm 0.05 \%)$ indicated poor flowability. Assessment on the Kawakita model showed good cohesion and densification. Compacts formed from the powders showed minimal variation in weight $(400 \mathrm{mg} \pm 5 \%$ ), were mechanically strong (hardness $97.45 \pm 2.02$ to $161.25 \pm 2.60 \mathrm{~N}$ and friability $(<1 \%)$. Heckel model assessment showed that powders displayed a plastic behaviour on compaction. The flow and compact indices obtained for MBPSP were within the British Pharmacopoiea (BP) acceptable limits, and compared well with those of emcompress ${ }^{\circledR}$ and avicel PH $101^{\circledR}$. Thus modified $T$. fuscata shell powder has a good potential as a directly compressible powder and further work may be required on it.
\end{abstract}

Keywords: Flow, compaction, modified, Tympanotonus fuscata, shell.

Article Info: Received 08 Feb, 2018; Review Completed 16 April 2018; Accepted 17 April 2018; Available online 20 April 2018

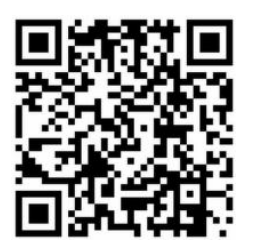

Cite this article as:

Ugoeze KC, Chukwu A, Flow and compaction properties of the modified biomaterial powder derived from the Tympanotonus fuscata shell, Journal of Drug Delivery and Therapeutics. 2018; 8(2):181-187 DOI: http://dx.doi.org/10.22270/jddt.v8i2.1708

*Address for Correspondence:

Kenneth C. Ugoeze, Department of Pharmaceutics \& Pharmaceutical Technology, Faculty of Pharmaceutical Sciences, University of Port Harcourt, Nigeria

\section{INTRODUCTION}

The molluscs usually have their exoskeletons considered as shells. Shells are hard, stiff surface $\mathrm{CaCO}_{3}$ layer of types of creatures. The shell, in addition to chitin, is also made of nacre, an organic mixture of superficial coat of horny conchiolin which is a scleroprotein. Nacre exudates from the ectodermic compartments of the layers of some types of Mollusca. The blood of mollusc is filled with calcium in solution and this crystalizes out as $\mathrm{CaCO}_{3}$. The deposits of $\mathrm{CaCO}_{3}$ may integrate conchiolin that fixes the $\mathrm{CaCO}_{3}$ crystals together. Bulky aggregates of shells may constitute residue and convert to limestone ${ }^{1}$. T. fuscata var radula (L) often called periwinkle is covered with shell and belongs to the phylum, Mollusca ${ }^{1-9}$. The practicability as inexpensive basis of protein especially in the south-south area of Nigeria where its collection and marketing constitute an important industry cannot escape mention ${ }^{\mathbf{1 0}}$. The empty shells hitherto discarded as waste with its accumulation adding to the environmental menace has found economic value as cheap substitute for chippings in building 
constructions, sources of calcium supplement in animal fodder, etc. ${ }^{11}$. Combusted periwinkle residue has been examined as a pozzolanic solid substance to possibly enhance the toughness and stability of cement work. This as well has been evaluated for its usefulness to possibly serve as substitute for regular Portland cement in concrete ${ }^{\mathbf{6}, 12-15}$. The preliminary characteristics of the biological stuff of $T$. fuscata shell applicable as inert substance in the compounding of medicinal products has been cited ${ }^{11}$. There are records of more examinations into the general characteristics of the modified biomaterial powder of periwinkle shell (MBPSP) ${ }^{16}$. The continuous search for affordable locally available pharmaceutical raw materials in developing countries led to the evaluation of the modified biomaterial of periwinkle shell powder as a potential tablet excipient. This investigation was fashioned to evaluate its flow and compaction properties using the Heckel and Kawakita models respectively since directly compressible solids demands materials that are flowable, compactable and compressible (17-22). These studies were investigated for MBPSP alongside emcompress ${ }^{\circledR}$ and microcrystalline cellulose (avicel PH $101^{\circledR}$ ).

\section{MATERIALS}

The following reagents were used employed in this study: hydrochloric acid, sodium hydroxide (M\&B, England), orthophosphoric acid (Sure Chem, England), avicel PH $101^{\circledR}$, emcompress ${ }^{\circledR}$ (FMC Corporation, USA) and magnesium stearate (BDH, England),

\section{METHODS}

\section{Preparation of modified biomaterial powder}

The method reported by Ugoeze and Chukwu was adopted ${ }^{\mathbf{1 6}}$. A $100 \mathrm{~g}$ of milled outer cover of $T$. fuscata was digested with $166 \mathrm{ml}$ of $2 \mathrm{M}$ hydrochloric acid and filtered. The clear acidic solution was neutralized with 5 $\mathrm{M}$ sodium hydroxide. A white precipitate obtained was washed severally and ortho-phosphoric acid was added in bits to the thick aqueous suspension of the precipitate until a thick, dehydrated mass was obtained. It was dried to constant weight at $60{ }^{\circ} \mathrm{C}$ in a hot air oven $\left(\right.$ Memmert ${ }^{\circledR}$ , England) and classified with a $250 \mu \mathrm{m}$ stainless steel sieve (Retch ${ }^{\circledR}$, Germany) and stored in amber coloured powder bottle.

\section{Particle density}

The particle density of the solid material was determined by the pycnometer method using $n$-hexane as the liquid. An empty $25 \mathrm{ml}$ pycnometer was weighed (W). It was filled with n-hexane, and excess fluid wiped off. The filled pycnometer was weighed $\left(\mathrm{W}_{1}\right)$. The difference between this and $\mathrm{W}$ was calculated as $\mathrm{W}_{2}$. A $0.5 \mathrm{~g}$ quantity of the powder was weighed $\left(\mathrm{W}_{3}\right)$ and carefully transferred into the pycnometer. The excess fluid was wiped off and the bottle was weighed again $\left(\mathrm{W}_{4}\right)$. Three determinations were carried out and the average was used to calculate the particle density from equation 1 below ${ }^{23}$ :

$$
D_{p}=W_{2} \times W_{3} / V\left(W_{3}-W_{4}+W_{2}+W\right)
$$

\section{Bulk density}

The bulk density of each sample (loose density) was evaluated by transferring $30 \mathrm{~g}$ of the powder into a 250 $\mathrm{ml}$ glass cylinder and the volume, $V_{o}$ was noted. The bulk density ${ }^{24}$ was computed from equation 2 .

$$
B d=W / V o \text {. }
$$

\section{Flow properties}

Flowability was determined using the Kawakita model for analysis $(19,20)$. Tapped density was determined using Stampfvolumeter (STAV 2003JEF ${ }^{\circledR}$, Germany) as a modified Neumann apparatus ${ }^{\mathbf{2 5}}$. The method involved transferring $15 \mathrm{~g}$ of each materials through an angle of $45^{\circ}$ into a $250 \mathrm{ml}$ glass cylinder. The bulk volume $\left(V_{o}\right)$ was measured. The cylinder was mechanically tapped repeatedly. Volume changes were recorded during the tapping process. The tapped densities relative to the number of taps $(\mathrm{N})$ were calculated from the weights and volumes. The pattern of the solid substances as they were tapped in the glass cylinder were likened employing arithmetical constants derived from the Kawakita plots.

The Kawakita equation $(19,20)$ used for assessing the flow behaviour of powders is as below:

$$
N / C=N / a+1 / a b
$$

Note: $a$ and $b$ are constants; $a$ defines the extent of volume decrease at the limit of tapping and is known as compactability, $1 / b$, is taken to be a constant connected to cohesion and is noted as cohesiveness. $C$, the extent of volume decrease is computed from the original volume $V_{o}$ and tapped volume $V_{N}$ as:

$$
C=\frac{\left(V_{O}-V_{N}\right)}{V_{N}}
$$

where $V_{N}$ is the volume at tapping number, $N$.

Numerical quantities for the mathematical constants $a$ and $1 / b$ are derived through the slope, $1 / a$ and the intercept, $1 / a b$ of the plots of $N / C$ against number of taps $N$.

\section{Compaction studies}

\section{Preparation of compacts}

Cylindrical compacts of each sample, average weight of $400 \mathrm{mg}$, were compressed for $30 \mathrm{~s}$ in a pressure applied compact machine (Model C, Carver Laboratory Press, Wisconsin, USA) at compression pressure units from 2.45 to $12.25 \mathrm{kN}$ respectively. Twenty compressed solids were made at each compression level per material for study. The diameter of the die and punch was 10.5 $\mathrm{mm}$. It was greased with $2 \% \mathrm{w} / \mathrm{v}$ of magnesium stearate suspended in a diethyl ether-ethanol (1:1) solution prior to compression. The compressed solids were kept overnight in desiccator containing silica gel for elastic recovery and toughening. The thickness and diameter of other batches were evaluated with a micrometer screw gauge (VIS, Poland). The compact weights were ascertained on chemical balance (Ohaus, China). Compact hardness was determined with a digital hardness tester (DBK Instrument, England). Tensile strength of the compressed solids was calculated. The 
relative density, $D$, was computed as the ratio of density of the compressed solids, $D_{t}$, to the particle density, $D_{p}$ of the excipient material. The figures got using this 'ejected tablet method' were employed in deriving the Heckel plots. Linear regression analysis was conducted over a compression range of 2.45 to $12.25 \mathrm{kN}$ and factors from Heckel plots were computed. The area under the Heckel curve (AUHC) was computed by the trapezoidal method and employed to estimate the degree of volume decrease or compressibility which the solid substance went through at the period of compression pressure range.

The plots designed in line with the Heckel equation, as in equation 5 , were utilized to estimate the compaction pattern of the powders.

$$
\operatorname{In}[1 /(1-D)]=K P+A
$$

Note: $D$ is the relative density of the compact. $P$ is the pressure applied. $K$ is the slope of the straight portion of the graph. It shows the decrease in the porosity or the resistance to volume decrease of solid materials. $A$ is the intercept. The yield pressure, $P_{y}$, is normally computed as the reciprocal of $K$. From the intercept A, the relative density $D_{A}$ may be estimated using equation 6 .

$$
D_{A}=1-e^{-A}
$$

The relative density, $D_{O}$ of the solid material at the stage at which the applied pressure is equivalent to zero is computed using equation 7 . It is utilized to define the original reorganization stage of densification due to die filling.

$$
D_{O}=\frac{\text { Bulk density }}{\text { Particle density }}
$$

The relative density $D_{B}$, describes the phase of arrangement during the original stages of compression. The extent of this depends on the theoretical point of densification at which particle deformation begins. $D_{B}$ is obtained from the difference between $D_{A}$ and $D_{O}$.

$$
D_{B}=D_{A}-D_{O}
$$

The tensile strength $T_{S}$ was computed using equation 9 in line with Fell and Newton's consideration ${ }^{\mathbf{2 0}}$.

$$
T_{S}=\frac{2 P}{\pi d h}
$$

Where $\mathrm{F}$ is the force or load required to diametrically break the compact, $\mathrm{d}$ and $\mathrm{h}$ are the compact diameter and thickness respectively.

\section{RESULTS AND DISCUSSION}

The results of the flow parameters of MBPSP, emcompress $^{\circledR}$ and avicel PH $101{ }^{\circledR}$ are presented in Table 1. The variation amid the bulk and tapped density readings indicates that there was a reasonable reduction in volume of the solid material on tapping. This is further supported by the high porosity value (70.31 \pm 0.01 ) which suggests that the percentage of spaces or voids is high. Thus MBPSP densifies on agitation of the solid material bed. The angle of repose, compressibility index and Hausner's quotient indicate that MBPSP is a poor flowing powder as the values obtained as presented in Table 1 exceeded the upper set limits for good powder flow by the BP measures ${ }^{\mathbf{2 6}}$. Comparing these values with those of emcompress ${ }^{\circledR}$ and Avicel PH $101^{\circledR}$ (Table 1 ), it can be seen that emcompress ${ }^{\circledR}$ has a superior flowability than both MBPSP and avicel PH $101^{\circledR}$, while MBPSP flows better than avicel PH $101^{\circledR}$. The compressed solids which were compressed at a target weight of $400 \mathrm{mg}$ per compact exhibited a minimal variation in weight. The compacts weighed between $399.90 \pm 1.91$ to $400.90 \pm 1.52 \mathrm{mg}$ (Table 2). These values conform to the BP's acceptable limits of coefficient of variation of $( \pm 5 \%)$ for uncoated tablets weighing above $250 \mathrm{mg}{ }^{\mathbf{2 6}}$. The compacts were mechanically strong as the hardness readings ranged between $97.45 \pm 2.12$ to $161.25 \pm 2.60 \mathrm{~N}$. These values were above $39.9 \mathrm{~N}$ which is considered the minimal hardness value for uncoated tablets if they are to resist the rigors and movement stresses the compacts may be exposed to. A plot of the hardness against compression pressure (Figure 2) shows that MBPSP compacts were harder than those of emcompress ${ }^{\circledR}$ but weaker than those of avicel PH $101^{\circledR}$. A similar pattern was shown in Figure 3 where the tensile strength of the compressed solids were considered. Hardness and tensile strength are good indices of the physical strength of a compact or tablet.

Figure 1 is a Heckel plot for the powder of MBPSP. The slope, $K$ of the linear portion is 0.04 and the intercept, $A$ equals 0.269 . The slope, $K$ of a Heckel plot gives a measure of the plasticity of a compressed material and the reciprocal is known as the yield pressure, $P_{Y}$ and has a value of 25 . Yield pressure indicates deformability of the material. The soft, ductile powders have lower yield pressure. This value is low for MBPSP and shows that the solid powder is compressible. The agglomerates with low yield value could be plastically deformed as a result of re-bonding of smaller primary crystals ${ }^{6}$. Low value of $P_{Y}$ shows low ability to yield to pressure, good solidification and ease of compressibility ${ }^{7}$. A high value of slope shows the onset of plastic deformation at relatively low pressure ${ }^{\mathbf{8}}$. Literature shows that deranging from linearity in some plots of $\ln [1 / 1-D]$ versus pressure often occur at low and high pressures. At low pressures, reduction in porosity is largely due to particle rearrangement, and thus, the true consolidation mechanism, i.e. fragmentation or deformation will be a minor component at this stage. At high pressures, porosity is usually very low and hence its reciprocal becomes a very large number ${ }^{9}$. Respective densities from Heckel plot of MBPSP are presented in Table 3.

The physical strength of a compact is reliant on on the extent and strength of inter-particulate bonds and these in turn are linked to the compressive force which is applied. Therefore, the relationship between the applied forces and on how strong the compressed material is serves as tool to know how fast a given substance will be compressed. It also provides an understanding into the compaction mechanism of the solid and its mechanical properties ${ }^{10}$. An important parameter in this relationship is the hardness, which is the force required to fracture a compact diametrically. In Figure 2, a correlation exists between hardness and compression pressure. A direct proportional relationship is also seen to exist in the plot of tensile strength against compression pressure for the material (Figure 3). The relationship existing between 
compression pressures and porosity is shown in Figure 4. It indicates that as the compression force is increased, porosity falls rapidly. The reduction in porosity with increasing compression pressure reflected in corresponding decrease in compact thickness. The existence of direct proportional relationship between hardness and tensile strength versus compression force shows that MBPSP may be very useful as a directly compressible material.

Table 1: Flow parameters of MBPSP, emcompress ${ }^{\circledR}$ and avicel PH $101^{\circledR}$

\begin{tabular}{|l|l|l|l|}
\hline Parameter/Material & MBPSP & EMCOMPRESS & AVICEL PH 101 \\
\hline Bulk density $(\mathrm{g} / \mathrm{ml})$ & $0.42 \pm 0.01$ & $0.86 \pm 0.03$ & $0.41 \pm 0.50$ \\
\hline Tapped density $(\mathrm{g} / \mathrm{ml})$ & $0.68 \pm 0.01$ & $1.02 \pm 0.10$ & $0.58 \pm 0.25$ \\
\hline Compressibility index $(\%)$ & $27.25 \pm 0.05$ & $15.69 \pm 0.01$ & $26.39 \pm 0.20$ \\
\hline Hausner's quotient & $1.36 \pm 0.12$ & $1.17 \pm 0.15$ & $1.36 \pm 0.10$ \\
\hline Flow rate $(\mathrm{g} / \mathrm{s})$ & $8.94 \pm 0.13$ & $16.04 \pm 0.02$ & Poor flow \\
\hline Angle of repose $\left(^{\circ}\right)$ & $35.18 \pm 0.49$ & $27.15 \pm 0.01$ & $49.87 \pm 0.30$ \\
\hline Porosity $(\%)$ & $70.31 \pm 0.01$ & $53.76 \pm 0.05$ & $76.30 \pm 0.03$ \\
\hline Particle density $(\mathrm{g} / \mathrm{ml})$ & $1.67 \pm 0.02$ & $1.86 \pm 0.03$ & $1.73 \pm 0.02$ \\
\hline
\end{tabular}

Table 2: Some compact parameters of MBPSP, emcompress ${ }^{\circledR}$ and avicel PH $101^{\circledR}$

\begin{tabular}{|c|c|c|c|c|c|c|}
\hline & & \multicolumn{5}{|c|}{ Compression Pressure $(\mathrm{kN})$} \\
\hline Excipient & Parameter & 2.45 & 4.90 & 7.35 & 9.80 & 12.25 \\
\hline \multirow{3}{*}{$\begin{array}{l}\hat{\tilde{n}} \\
\tilde{n} \\
\stackrel{n}{\Sigma}\end{array}$} & $\begin{array}{l}\text { Compact weight } \\
(\mathrm{mg}) \pm \% *\end{array}$ & $\begin{array}{r}399.90 \\
\pm 1.91\end{array}$ & $\begin{array}{r}400.90 \\
\pm 1.52\end{array}$ & $\begin{array}{l}400.70 \\
\pm 1.76\end{array}$ & $\begin{array}{r}400.50 \\
\pm 1.58\end{array}$ & $\begin{array}{l}400.50 \\
\pm 1.55\end{array}$ \\
\hline & Friability $(\%)$ & $\begin{array}{l}0.85 \\
\pm 0.01\end{array}$ & $\begin{array}{l}0.70 \\
\pm 0.21\end{array}$ & $\begin{array}{l}0.62 \\
\pm 0.05\end{array}$ & $\begin{array}{l}0.31 \\
\pm 0.02\end{array}$ & $\begin{array}{l}0.30 \\
\pm 0.01\end{array}$ \\
\hline & Thickness (mm) & $\begin{array}{l}3.05 \\
\pm 0.06\end{array}$ & $\begin{array}{l}2.43 \\
\pm 0.11\end{array}$ & $\begin{array}{l}2.19 \\
\pm 0.05\end{array}$ & $\begin{array}{l}2.11 \\
\pm 0.07\end{array}$ & $\begin{array}{l}2.11 \\
\pm 0.04\end{array}$ \\
\hline \multirow{3}{*}{ 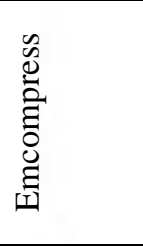 } & $\begin{array}{l}\text { Compact weight } \\
(\mathrm{mg})^{*}\end{array}$ & $\begin{array}{l}399.13 \\
\pm 1.46 \\
\end{array}$ & $\begin{array}{r}399.70 \\
\pm 1.98 \\
\end{array}$ & $\begin{array}{l}400.00 \\
\pm 2.78 \\
\end{array}$ & $\begin{array}{r}400.13 \\
\pm 1.81 \\
\end{array}$ & $\begin{array}{r}400.50 \\
\pm 1.60 \\
\end{array}$ \\
\hline & Friability $(\%)$ & $\begin{array}{l}0.45 \\
\pm 0.03 \\
\end{array}$ & $\begin{array}{l}0.40 \\
\pm 0.20 \\
\end{array}$ & $\begin{array}{l}0.30 \\
\pm 0.01 \\
\end{array}$ & $\begin{array}{l}0.28 \\
\pm 0.11 \\
\end{array}$ & $\begin{array}{l}0.26 \\
\pm 0.50 \\
\end{array}$ \\
\hline & Thickness (mm) & $\begin{array}{l}3.05 \\
\pm 0.02 \\
\end{array}$ & $\begin{array}{l}2.97 \\
\pm 0.04\end{array}$ & $\begin{array}{l}2.96 \\
\pm 0.02 \\
\end{array}$ & $\begin{array}{l}2.86 \\
\pm 0.03 \\
\end{array}$ & $\begin{array}{l}2.84 \\
\pm 0.03 \\
\end{array}$ \\
\hline \multirow{3}{*}{$\begin{array}{l}\overline{0} \\
\bar{T} \\
\overline{0} \\
\bar{d} \\
\frac{0}{2}\end{array}$} & $\begin{array}{l}\text { Compact weight } \\
(\mathrm{mg})^{*}\end{array}$ & $\begin{array}{l}402.80 \\
\pm 1.60\end{array}$ & $\begin{array}{l}401.60 \\
\pm 2.42\end{array}$ & $\begin{array}{l}402.61 \\
\pm 2.06\end{array}$ & $\begin{array}{l}401.40 \\
\pm 1.36\end{array}$ & $\begin{array}{l}402.00 \\
\pm 1.74\end{array}$ \\
\hline & Friability $(\%)$ & $\begin{array}{l}0.50 \\
\pm 0.01\end{array}$ & $\begin{array}{l}0.38 \\
\pm 0.31\end{array}$ & $\begin{array}{l}0.31 \\
\pm 0.13\end{array}$ & $\begin{array}{l}0.25 \\
\pm 0.22\end{array}$ & $\begin{array}{l}0.25 \\
\pm .01\end{array}$ \\
\hline & Thickness (mm) & $\begin{array}{l}3.95 \\
\pm 0.07\end{array}$ & $\begin{array}{l}3.79 \\
\pm 0.03\end{array}$ & $\begin{array}{l}3.71 \\
\pm 0.04\end{array}$ & $\begin{array}{l}3.66 \\
\pm 0.04\end{array}$ & $\begin{array}{l}3.65 \\
\pm 0.02\end{array}$ \\
\hline
\end{tabular}

Represents coefficient of variance

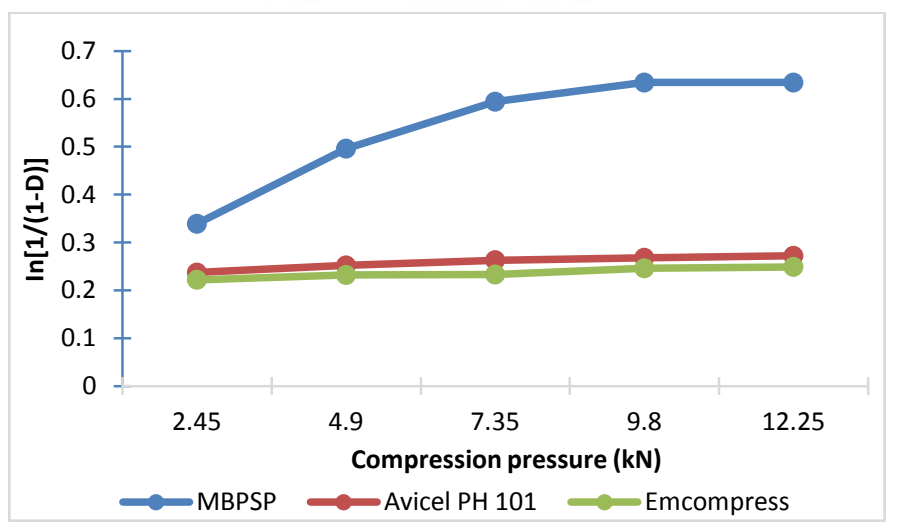

Figure 1: Heckel plot of MBPSP, Avicel PH101 ${ }^{\circledR}$ and Emcompress ${ }^{\circledR}$ 
Table 3: Parameters derived from Heckel plots of MBPSP, Emcompress ${ }^{\circledR}$ and Avicel PH101 ${ }^{\circledR}$

\begin{tabular}{|c|c|c|c|}
\hline \multirow{2}{*}{ Parameter } & \multicolumn{3}{|c|}{ Values } \\
\cline { 2 - 4 } & MBPSP & Emcompress $^{\circledR}$ & ${\text { Avicel PH } 101^{\circledR}}^{\circledR}$ \\
\hline $\mathrm{D}_{\mathrm{A}}$ & 1.379 & 1.241 & 1.265 \\
\hline $\mathrm{D}_{\mathrm{O}}$ & 0.251 & 0.383 & 0.201 \\
\hline $\mathrm{D}_{\mathrm{B}}$ & 1.128 & 0.858 & 1.064 \\
\hline $\mathrm{K}$ & 0.029 & 0.002 & 0.003 \\
\hline $\mathrm{A}$ & 0.321 & 0.216 & 0.235 \\
\hline $\mathrm{P}_{\mathrm{y}}$ & 34.483 & 500.000 & 333.330 \\
\hline
\end{tabular}

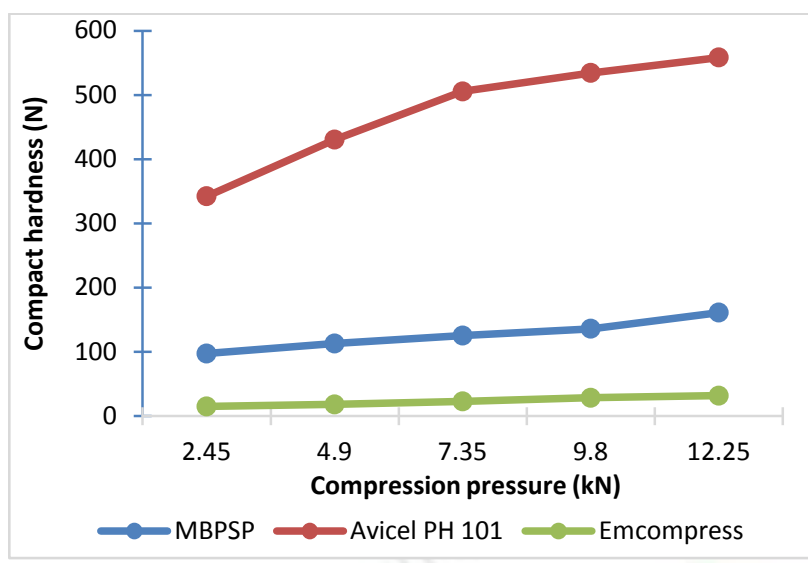

Figure 2: Compact hardness against compression pressure of MBPSP, Avicel (PH101) and Emcompress

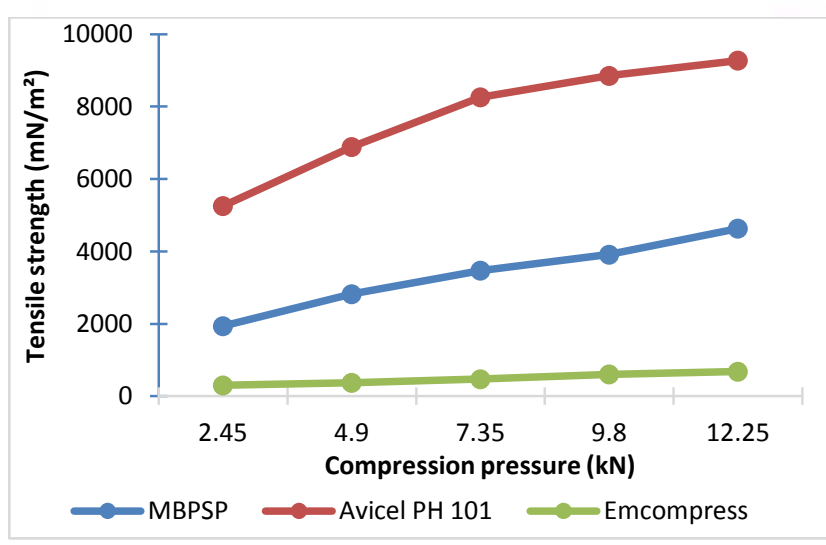

Figure 3: Compression pressure against compact tensile strength of MBPSP, Emcompress and Avicel PH101 and Emcompress

From the graphical illustration in Figure 4, it could be observed that the alteration in porosity in response to increasing compression pressure was decreasing, signifying plastic deformation. When the particles are in the die of a machine used to compress a tablet and a progressively increasing force is applied, the particle will go through a rearrangement phase to form a lower porous structure. It occurs at low force as the particles slide past each other. This stage is usually associated with some fragmentation, as the rough surfaces move passing other particles ${ }^{\mathbf{1 0}}$. The particles will normally reach the stage where relative movement becomes impossible, although the porosity of the powder bed may still be considerable. At this stage, a further increase in

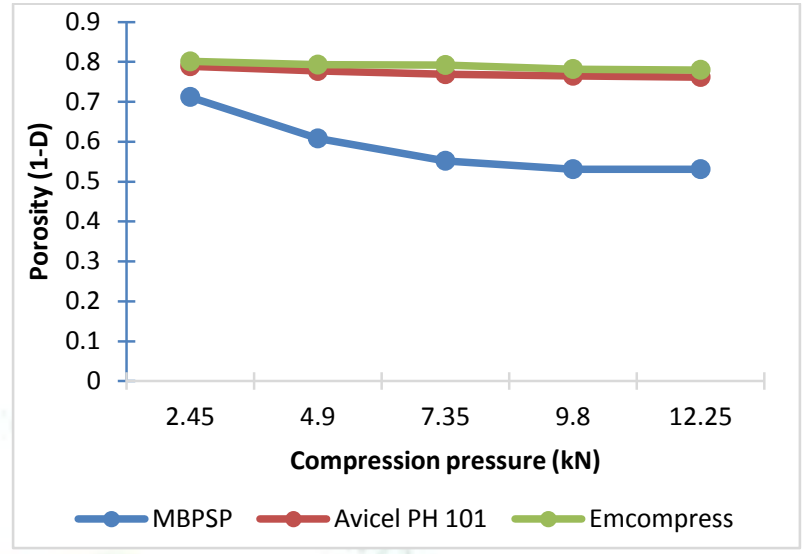

Figure 4: Plot of compression pressure against compact porosity of MBPSP, Avicel (PH 101) and Emcompress

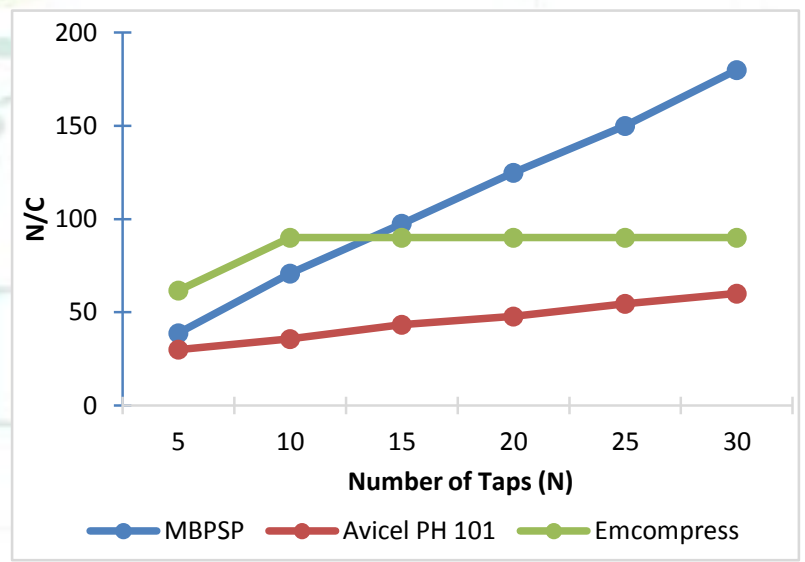

Figure 5: Kawakita plots of MBPSP, Avicel and Emcompress

applied force will progressively induce elastic deformation, plastic deformation, or fragmentation. Which of these situations predominates, will depend on the properties of the material involved, but the net result will be an increase in inter particulate contact. If only elastic deformation has occurred, then when the compression force is removed, the particles will return to their former shape. The inter-particulate contact caused by compression will be lost and a non-coherent compact will be formed ${ }^{10}$.

If, however, plastic deformation occurs, as the force is removed, not all the increased inter-particulate contact will be lost, cohesion will be retained and a hard 
compact will be formed. Thus, from the point of view of forming a hard compact, substances with low elastic limits, which undergo plastic deformation at low compressive forces, are preferable to more elastic bodies. If consolidation of the powder mass is brought about by fragmentation, then a large number of points of inter particulate contacts are created, from which the strength of the compacts is derived ${ }^{\mathbf{1 0}}$. In this case, removal of the compressing force should have no effect on the compact strength, since there are no ways the fragments can recombine into the original particles.

The MBPSP powder seems to follow this principle. Compacts compressed at various pressures exhibited hardness and tensile strength which were high enough. If the porosity value at which the curve becomes horizontal is dependent on the solid being compressed, and substances that deform plastically typically give compacts of lower porosity than those which fragment, then from all indications, MBPSP must have undergone plastic deformation under high compression pressure.
Figure 5 is a representative Kawakita plot for the powders of MBPSP, Emcompress and Avicel PH 101. A linear relationship was obtained. The parameters derived from the plot are shown in Table 3 . The plot has a slope, $a$ of 5.55 and an intercept $b$ of 13.21 with a correlation coefficient of 0.998. Kawashima et al. ${ }^{11}$ have reported that small figures of the constant $a$, indicate good packing even without tapping. They also reported that large values of $b$ indicate rapid packing velocity. The results obtained for the powder of MBPSP are consistent with this report.

The reciprocal of $b$, defines a pressure term, $P x$, which is the pressure required to reduce the powder bed by $50 \%$ $\mathbf{1 2}^{\mathbf{1 2}} \mathrm{Or}$, it describes cohesiveness of powders or the ease with which the final packing stage is attained ${ }^{\mathbf{1 4}}$. The value of $P_{X}$ of 0.08 could be taken to be low. Low values of $\mathrm{P}_{\mathrm{X}}$ indicate materials that are ductile and distort plastically when subjected to pressure ${ }^{\mathbf{1 5}}$.

Table 3: Constants derived from Kawakita plots of MBPSP, Emcompress and Avicel (PH 101)

\begin{tabular}{|l|c|c|c|}
\hline \multirow{2}{*}{ Parameter } & \multicolumn{2}{|c|}{ Values } & Avicel PH 101 $^{\circledR}$ \\
\cline { 2 - 4 } & MBPSP & Emcompress $^{\circledR}$ & 1.21 \\
\hline Slope $a$ & 5.55 & 0.81 & 24.10 \\
\hline Intercept, $b$ & 13.23 & 71.11 & 0.04 \\
\hline $\mathrm{P}_{\mathrm{x}}$ & 0.08 & 0.02 & \\
\hline
\end{tabular}

\section{CONCLUSION}

The modified biomaterial derived from periwinkle shell (MBPSP) had a poor flow. This factor would be disadvantageous in the application of MBPSP in the making of compacts using high speed tableting machines. The cohesive nature of the solid particles would not allow it to be properly discharged from the hoppers of such high speed press unless induced die feeders are employed. However its ability to undergo volume reduction coupled with a good compressibility permitted the manufacture of good, strong compacts with a good uniformity of weight. This would enable its performance as an excipient that would permit the production of a decent tablet containing the active pharmaceutical ingredient. The compacts compressed from MBPSP powder had good physical qualities such as uniformity of weight, hardness and tensile strength which confirm the good mechanical properties of the compacts. Disintegration and friability were within BP acceptable set limits. The mechanical strength of
MBPSP compact was greater than that of emcompress ${ }^{\circledR}$ but was less than that of avicel PH $101^{\circledR}$ compacts.

The hardness and tensile strength of the compressed solids obtained from MBPSP were high and both showed directly proportional relationship to compression pressure. This shows that the substance is cohesive and that hard compacts or tablets could be got from its use with increased pressure loads. Compact thickness and porosity showed inverse relationships to increasing compression pressure, showing that the material is compressible. Data generated from the Heckel and Kawakita plots confirm the compressibility of the material. At high compression pressure, plastic deformation became dominant, and there was no connotation of fragmentation. These properties indicate that MBPSP has the potentials of direct compression diluent.

Conflict of interest: The authors declare no conflict of interest.

\section{REFERENCES}

1. Francis, H. (2006), "How are seashells created"? Scientific American, Available from www.scientificamerican.com. Retrieved on $7^{\text {th }}$ January, 2015.

2. Olaniyan, C.I.O. (1978), “An introduction to West African animal ecology: Heinemann educational books, London and Ibadan. $2^{\text {nd }} E d n ; 170$.

3. Olorunoje, G.S and Olalusi, O.C., "Periwinkle shell as alternative to coarse aggregate in lightweight concrete", International Journal of Environmental; 2003; 1(1):231-236.

4. Edmund, J., "Sea shells \& other mollusc found on West African shores \& estuaries". In: Descriptive manual of Janet Edmund. Ghana University press, Accra, 1978; 20, 100-101.

5. Buchaan, J.B., "Marine molluscs of Gold Coast of West Africa". J. West African Sci. Assoc; 1954; 7:30-45.

6. Badmus, M.A.O, Audu, T.O.K. and Anyata, B.U., "Removal of lead ion from industrial waste waters by activated carbon prepared from periwinkle shell (Tympanotonus fuscatus)". Turkish Journal of Engineering and Environmental Science 2007; 31:251-263. 
7. Job, O. F. (2008), "The durability characteristics of periwinkle shell concrete". Ph.D. Thesis, University of Jos, Nigeria.

8. Jamabo, N. and Chinda. A., "Aspects of the ecology of Tympanotonous fuscatus var fuscatus (Linnaeus, 1758) in the mangrove swamps of the Upper Bonny River, Niger Delta, Nigeria". Current Research Journal of Biological Sciences; 2010; 2(1): 42-47.

9. Mmom, P.C. and Arokoya, S.B., "Mangrove forest depletion, biodiversity loss and traditional resources management practices in the Niger Delta, Nigeria". Research Journal of Applied Sciences, Engineering and Technology, 2010; 2(1):28-34.

10. Powell, C.B, Hart, A.I. and Deekae, S., "Market survey of the periwinkle, Tympanotonus fuscatus in Rivers State: sizes, prices, trade routes and exploitation levels". Proceedings of the 4th annual conference of the Fisheries Society of Nigeria (FISON), Port-Harcourt, Nigeria. 1985.

11. Ugoeze, K.C and Chukwu, A., "Preliminary evaluation of the properties of biomaterial of Tympanotonus fuscata shell as pharmaceutical excipient". Int. Res. J. Pharm. 2015; 6(2):104-107.

12. Dahunsi, B.I.O. and Bamisaye, J.A., "Use of periwinkle shell ash (PSA) as partial replacement for cement in concrete". Proceedings: Nigerian Materials Congress and Meeting of Nigerian Materials Research Society, Akure, Nigeria, 2002; 184-186.

13. Job, O.F; Umoh, A.A. and Nsikak, S.C., "Engineering properties of sand-crete blocks containing periwinkle shell ash and ordinary Portland cement". International Journal of Civil Engineering, 2009; 1:18- 24.

14. Olutoge, F.A; Okeyinka, O.M. and Olaniyan, O.S., "Assessment of the suitability of periwinkle shell ash (PSA) as partial replacement for ordinary Portland cement (OPC) in concrete". International Journal of Research and Reviews in Applied Sciences 2012; 10(3):428 - 434.

15. Olusola, K.O. and Umoh, A.A., "Strength characteristics of periwinkle shell ash blended cement concrete". International
Journal of Architecture, Engineering and Construction 2012; 1(4):213-220.

16. Ugoeze, K.C. and Chukwu, A.. Physico-Chemical Properties of a Modified Biomaterial from Tympanotonus Fuscata (Periwinkle) Shell Powder Considered As Pharmaceutical Excipient, Journal of Pharmaceutical and Allied Sciences, 2017; 14(1):2429.

17. Heckel, R.W. Density-pressure relationships in powder compaction, Trans. Metall. Soc. AIME, 1961; 221:671.

18. Heckel, R. W. An analysis of powder compaction phenomena. Trans. Metall. Soc. AIME., 1961; 221:10011008 .

19. Kawakita, K and Ludde, K.H. Some consideration on powder compression equations, Powder Technol. 4(2):61-68.

20. Fell J.T. and Newton, J.M. (1970). Determination of tablet strength by the diametrical compression test, J. Pharm.Sci. 1970; 59:688-691.

21. Kawakita K.; Yamashiro M and Yuasa Y. An experimental study on the relationship between compressibility, fluidity and cohesion of powder solids at small tapping numbers, Powder Technol. 1983; 34:61-68.

22. Ertel K.D; Zoglio M.A.; Ritschel W.A. and Carstensen J.T. Physical aspects of wet granulation IV: effects of kneading time on dissolution rate and tablets properties, Drug Dev. Ind. Pharm. 1990; 16(6):963-981.

23. Odeku OA, Awe OO, Popoola B, Odeniyi MA, Itiola OA. Compression and mechanical properties of tablet formulations containing corn, sweet potato and cocoyam starches as binders. Pharm. Technol. 2005; 29(4):82-90.

24. Shangraw R.F.; Wallace J.W. and Bowers F.M. Morphology and functionality in tablets excipients for direct compression, Part 1, Pharm.Technol, 1981; 5:69-78.

25. Paronen P. and IIIka J., Porosity-pressure function, in: Pharmaceutical Powder Compaction Technology, Alderborn, G., Nystrom, C. Eds.; Marcel Dekker, Inc. New York, 1996, pp 55-75.

26. British Pharmacopoeia: Her Majesty Stationary Office, University Press, Cambridge, 2012: A326-A327. 